\section{ECONOMICS}

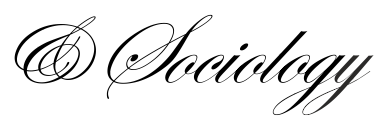

\title{
JOB SATISFACTION AMONG SMES EMPLOYEES IN FIBRES \& TEXTILES OF THE CEE COUNTRIES
}

\author{
Małgorzata Smolarek \\ Humanitas University, \\ Poland \\ E-mail:msmolarek@poczta.fm \\ ORCID 0000-0002-3766-8843

\section{Lukasz Sułkowski} \\ University of Social Sciences, \\ Poland \\ E-mail:sulkowskil@san.edu.pl \\ ORCID 0000-0002-1248-2743
}

Received: October, 2019

1st Revision: February, 2020

Accepted: June, 2020

DOI: $10.14254 / 2071-$

789X.2020/13-2/13
JEL Classification: M12, M54
ABSTRACT. Purpose. The purpose of this study is to identify the determinants affecting employees' professional satisfaction at small and medium-sized enterprises in the fibres and textile industry of the CEE countries. Design/methodology/approach - This empirical research is quantitative. The project investigated employee satisfaction at small and medium-sized enterprises. The sample consists of the data on 295 employees in fibres \& textiles. The research was conducted in four countries belonging to the CEE countries, i.e., Poland, Czech Republic, Slovakia and Lithuania. Findings - A number of positive answers regarding satisfaction with work corresponds to the social capital index. While assessing the factors affecting job satisfaction, workers' relations and company communication as well as constancy and stability of employment were positively assessed by the employees. The incentive and remuneration systems in force were evaluated negatively. Research limitations/implications The study was limited to the selected job satisfaction factors. The size of the research sample was not large enough to generalize the conclusions. The study was conducted using a self-designed questionnaire. Practical implications - Employers in the fibres and textile industry should pay more attention to their workers' satisfaction, assuming that an increased level of satisfaction can contribute to an increased work efficiency, bringing measurable results. Originality/value - Although there are many studies dedicated to job satisfaction, a relatively limited number of such researches are focused on employees of small and medium-scale enterprises operating in the fibers \& textiles branch. The article is, hence, an attempt to fill the aforementioned gap. Conducting the research in more than one country is sufficient enough to learn about the relationship between social capital and employee satisfaction.

Keywords: job satisfaction, social capital, CEE countries, SME, fibres \& textile industry 


\section{Introduction}

Currently, there is a fairly widespread opinion that social capital is indispensable for effective and innovative use of existing resources of both financial and human capital. It adds value to people who have capacity, knowledge, skills and other resources to be useful to employers or to run their own business effectively (Kuzkin et al., 2019). It is also the ability to work together to achieve mutual benefits. While human capital is created thanks to the skills and abilities of people, social capital facilitates the implementation of tasks through changes in relationships between people and can be capitalized to achieve individual goals (Marjanski \& Sulkowski, 2019).

Due to the fact that people are one of the most important resources that contemporary economic organizations have, employee satisfaction is of great importance for the functioning of the entire organization regardless of its size. It translates into both its results and development. For this reason, the problem of job satisfaction becomes a goal and a measure of organizational efficiency for modern organizations. Satisfied employees are particularly valuable because of their initiative, loyalty to the employer, favorable working climate they create and a significantly lower level of absenteeism. A positive relationship was also found between satisfaction and the level of workers' commitment to task performance, employment stability, level of service quality, customer loyalty and enterprise development (Sowińska, 2014, p. 45). Employers should be aware that increasing work efficiency is one of the most desirable effects of professional work, as it leads to an increase in the efficiency of the entire organization. On the other hand, high work results are equated with employee satisfaction. Consequently, it is worth ensuring that the employee maintains it at a high level.

The importance of satisfaction is also expressed in the fact that it has an impact on workers' attitudes towards tasks, profession and organization, being an important element of their competence potential.

The purpose of this study is to identify the determinants affecting employee professional satisfaction at small and medium-sized enterprises in the fibres and textile industry in the CEE countries. The following question was asked as a key research question: What are the main factors affecting employee satisfaction at SMEs in the fibres and textile industry of the CEE countries?

\section{Literature review}

\subsection{Fibres \& Textile SMEs in CEE Countries}

Central and Eastern European countries (CEECs) include ${ }^{1}$ Bulgaria, Croatia, the Czech Republic, Hungary, Poland, Romania, Slovakia, Slovenia and three Baltic countries: Estonia, Latvia and Lithuania.

The CEE countries form a dense international region, located between Western Europe and the Russian Federation, characterized by a similar geopolitical location, as well as common socio-historical experiences and development factors. Until recently, they operated under the conditions of the political and economic system that was a denial of democracy and a free market. Moreover, for almost half a century they were deprived of real independence. Three of these countries (Estonia, Lithuania and Latvia) did not even have apparent formal attributes of the state sovereignty. No wonder that today they differ from the so-called old EU, having a lower level of development and a weaker international competitive position.

\footnotetext{
${ }^{1}$ According to the OECD classification, the CEE countries also include Albania. However, due to the fact that this country does not belong to the EU, it was not included in the study (OECD, 2019).
} 
The CEE countries represent a relatively small but very diverse territorial, demographic and economic potential. Only Poland has a larger territory among them (6th place in the EU). Romania is also a relatively large country, followed by Bulgaria and Hungary. Other countries have an area of just several dozen thousand $\mathrm{km}^{2}$. The population of this region is $20.3 \%$ of the total EU population. Its density here is much lower than the EU average and very diverse: the lowest population can be observed in the northern part (Estonia, Latvia), whereas the highest population is in the central part (Czech Republic, Poland) (Ignasiak-Szulc \& Kosiedowski, 2016, p. 22).

After the accession of CEE countries to the EU, most of them took the last positions in the Community rankings. The pace of long-term growth and accession to the European Union were the most important areas in which it was possible to achieve a standard of living in the countries of Central and Eastern Europe in accordance with much higher Western countries (Cichowicz \& Rollnik-Sadowska, 2018, p. 1).

In the case of CEE countries, there are many similarities, including primarily: weak regional convergence, which is the result of different levels of individual macroregion countries' development; a slight tendency to polarize development processes at the regional level; economic structure of the less developed regions is dominated by activities with low added values (Smętkowski and Wójcik, 2008, p. 3, 83). Nevertheless, projects are underway for social and economic convergence. Thanks to this, the distance separating CEECs from highly developed Western Europe is slowly but steadily decreasing (Wierus et al., 2017, p. 5).

Despite many similarities between the CEE countries, there are also differences in the level of their regional development (resulting largely from different economic structures and employment rates of individual regions). Despite gradual improvement, the problem of sustainable development in the CEE countries remains an issue that requires considerable attention. According to the research (Raszkowski and Bartniczak, 2019, p. 14), currently none of the CEE countries belongs to the group characterized by a favorable situation in this area. Slovenia and the Czech Republic came close to achieving this goal in 2016, but ultimately remained together with Estonia, Hungary, Slovakia, Poland, Lithuania, Latvia and Croatia in a group of moderate sustainable development. The worst (unfavorable) situation in this respect was recorded in Bulgaria and Romania.

Small and medium-sized enterprises (SMEs) play an important role in the economy of every market. In market economy conditions SMEs determine the economic strength of a given country. Individual CEE countries show differences in the distribution of SMEs (Figure 1). In most CEE countries (the Czech Republic, Slovakia, Slovenia), the number of SMEs per 1000 inhabitants (aged 15 or over) has exceeded the EU-28 average from 50\% to just over $100 \%$. In turn, in several countries (Bulgaria, Poland, Croatia and Romania) this number was below the EU average. This large variation in the number of SMEs per 1000 inhabitants (15 years or more) reflects a number of different factors, such as the economy industrial structure, adoption and promotion of public policies that encourage self-employment and business creation, in particular micro enterprises, level of entrepreneurship and general economic and political conditions. Some authors consider that fact also regarding to availability of the EU funds to finance innovation in small and medium-sized enterprises (Koišová et al., 2018).

For the countries surveyed, the importance of the SME sector is derived from their significant contribution to creating added value and jobs, but with some differences between countries (see Figure 2). When it comes to contributing to value added, the Czech Republic, Hungary, Slovakia, Poland and Romania are below the EU28 average (56.8\%). Estonia (75.5\%) has the highest share (European Commission, 2018, p. 14). For employment, the SME sector uses over two-thirds of the workforce resources in four countries where the EU28 average (66.4\%) is considerably exceeded: Bulgaria (75.4\%), Lithuania (76.1\%), Estonia (77.9\%) and Latvia (79.0\%). Romania is below the EU average (65.8\%). 
SME is a heterogeneous sector. In addition to spatial diversity, sectoral diversity can be observed. Fibres and textile manufacturing is an example of the industry which relies on a great number of SMEs. Fibres and textiles belong to the light industry. The fibres and textile industry is one of the most labor-intensive sectors of the economy. At the same time, it is the least effective.

The textile and clothing sector is an important part of the European manufacturing industry, having a significant share in the economy and social well-being for many regions of Europe. According to the Eurotax data from 2017, there were 176,400 companies in the industry employing 1.7 million people and generating a turnover of EUR 181 billion (Šajn, 2019 , p. 2). The sector is responsible for a 3\% share in value added and a $6 \%$ share in employment in total production in Europe (Textiles and clothing in the EU). Figure 3 shows the number of enterprises operating in the textile and clothing sector in individual CEE countries in 2016. Table 1 presents data on the number of enterprises (active, newly created, liquidated) and the number of employees in the textile and clothing industry.

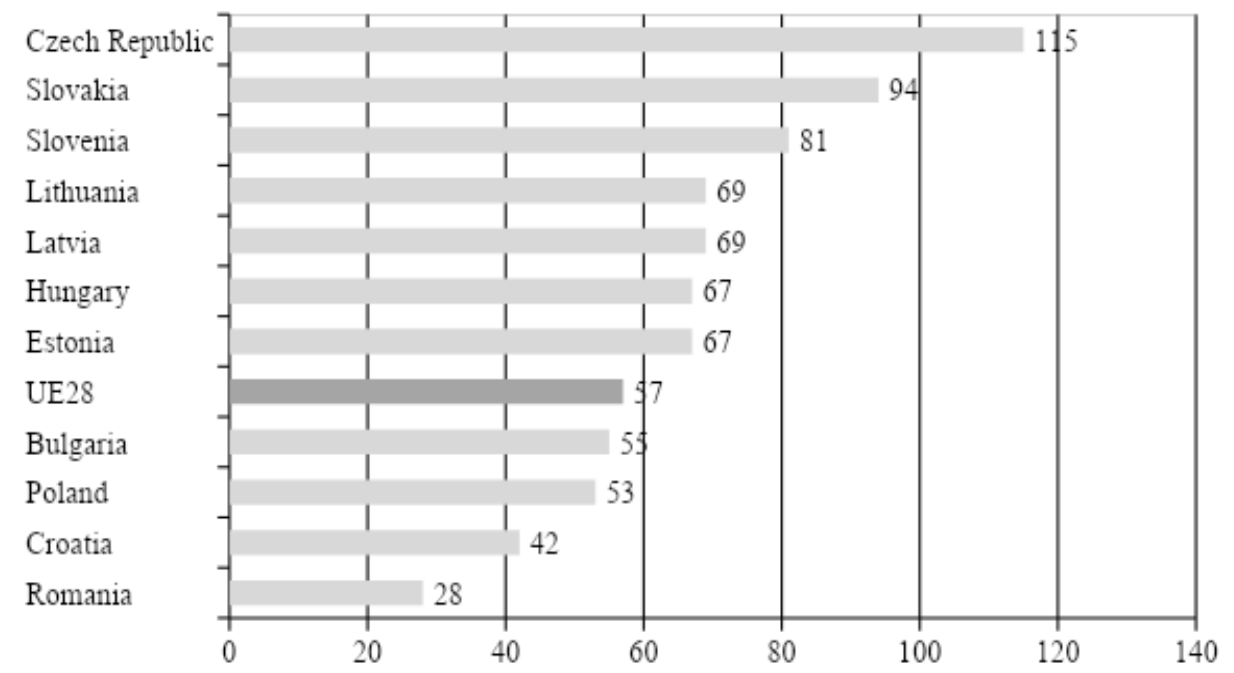

Figure 1. The number of SMEs per 1000 inhabitants in the non-financial enterprise sector in CEE countries in 2017

Source: processed data from European Commission (2018), p. 15.

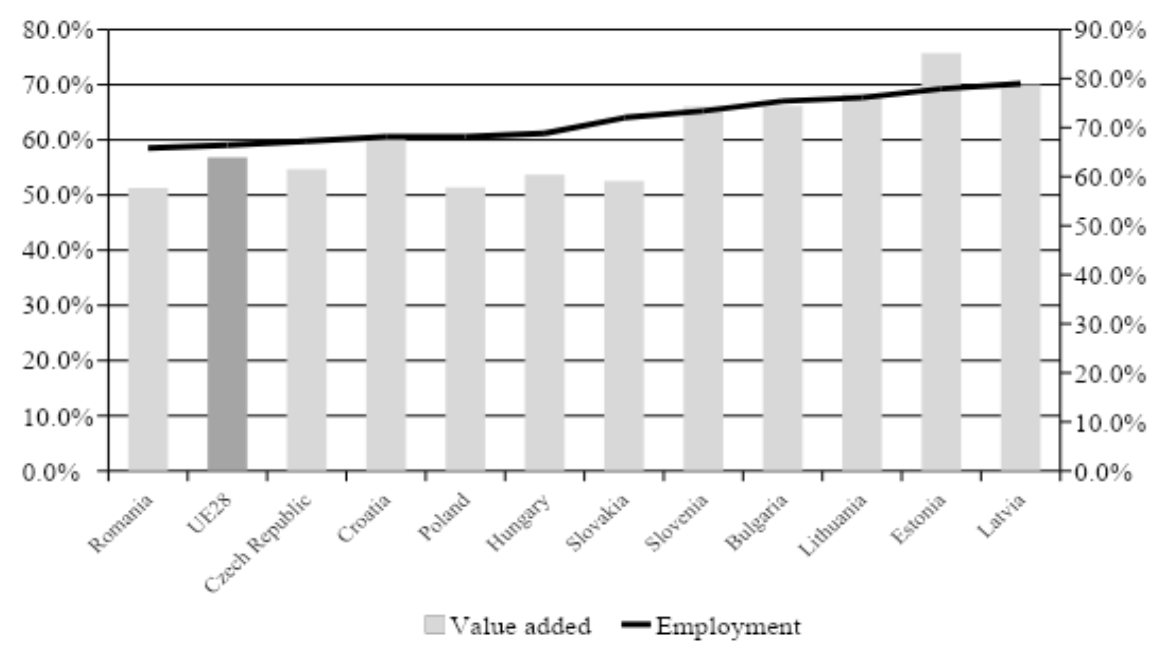

Figure 2. The role of the SME sector in the CEE countries in year 2017

Source: processed data from European Commission (2018), p. 16. 


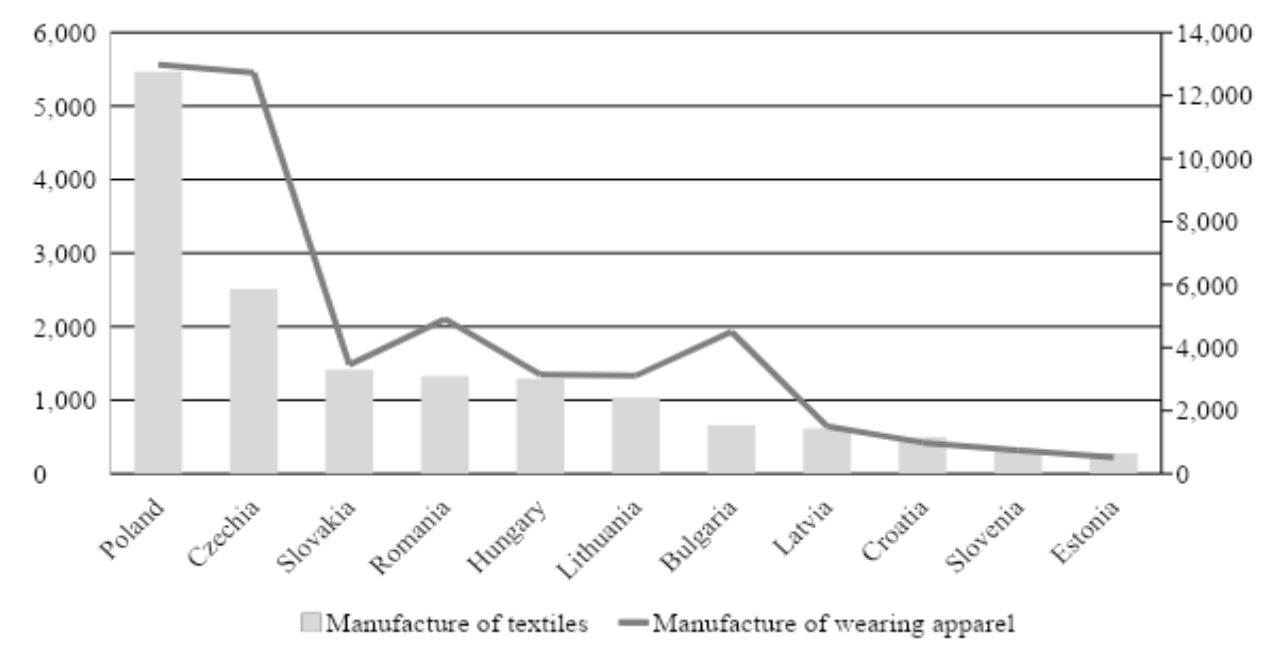

Figure 3. Textile and clothing sector in CEE countries in 2016

Source: processed data from Eurostat (2019).

Table 1. Number of enterprises active in the textile and clothing sector in CEE countries in 2016

\begin{tabular}{lcccc}
\hline & $\begin{array}{c}\text { Total number } \\
\text { of } \\
\text { active enterprises }\end{array}$ & $\begin{array}{c}\text { Total number } \\
\text { of } \\
\text { newly created } \\
\text { enterprises }\end{array}$ & $\begin{array}{c}\text { Total number of } \\
\text { liquidated } \\
\text { enterprises }\end{array}$ & $\begin{array}{c}\text { Employees in } \\
\text { active enterprises }\end{array}$ \\
\hline Bulgaria & 3851 & 384 & 393 & 97170 \\
\hline Czech Republic & 2326 & 276 & 247 & 36349 \\
\hline Estonia & 692 & 90 & 64 & 9367 \\
\hline Croatia & 983 & 60 & 79 & 16677 \\
\hline Latvia & 817 & 165 & 36 & 9326 \\
\hline Lithuania & 867 & 43 & 42 & 25982 \\
\hline Hungary & 2773 & 401 & 1393 & 120049 \\
\hline Poland & 10520 & 1389 & no data & 170665 \\
\hline Romania & 5319 & 550 & 559 & 4727 \\
\hline Slovenia & 477 & 40 & 50 & 17888 \\
\hline Slovakia & 1232 & 161 & 128 & \\
\hline
\end{tabular}

Source: processed data from Eurostat (2019).

Table 2 contains information on the number of micro-enterprises in 2016 in individual CEE countries.

An important feature of the EU textile and clothing industry is intra-regional trade. Despite growing pressure from competing Asian suppliers, the World Trade Organization (WTO) statistics show that throughout the EU, textile imports amounted to USD 89 billion in 2016 , of which $1 / 44,1 \%$ (USD 57 billion) belonged to the category of intra-regional trade. Similarly, in the case of clothing imports in the EU countries with a total value of USD 198 billion in 2016 as much as 55.6\% (USD 110 billion) came from other EU members. For comparison, nearly $97 \%$ of clothing used in 2016 in the United States was imported, of which over $75 \%$ came from Asia (Lu, 2018). 
Table 2. The number of micro-enterprises active in the textile and clothing sector in CEE countries in 2016

\begin{tabular}{lccc}
\hline & $\begin{array}{c}\text { Number of active } \\
\text { enterprises } \\
\text { (with 1-9 employees) }\end{array}$ & $\begin{array}{c}\text { Number of newly } \\
\text { created enterprises } \\
\text { (employing 1-9 } \\
\text { employees) }\end{array}$ & $\begin{array}{c}\text { Number liquidated } \\
\text { enterprises (employing } \\
\text { 1-9 employees) }\end{array}$ \\
\hline Bulgaria & 2349 & 329 & 318 \\
\hline Czech Republic & 1696 & 267 & 232 \\
\hline Estonia & 512 & 87 & 57 \\
\hline Croatia & 752 & 57 & 74 \\
\hline Latvia & 627 & 163 & 37 \\
\hline Lithuania & 454 & 39 & 1340 \\
\hline Hungary & 2329 & 396 & no data \\
\hline Poland & 7738 & 1322 & 481 \\
\hline Romania & 3193 & 452 & 115 \\
\hline Slovenia & 389 & 40 & 155 \\
\hline Slovakia & 946 & & 46 \\
\hline
\end{tabular}

Source: processed data from Eurostat (2019).

EU textile and clothing companies have a long tradition of cooperating with their counterparts from the candidate and acceding countries, where the textile and clothing sector plays an important role in the economy. First and foremost, these are outward processing contracts that allow the use of cheaper labor available outside the EU. There is already a high degree of economic integration between candidate and acceding countries and the EU. From $15 \%$ to $90 \%$ of exports from these countries is directed to current and future EU member states, while from $45 \%$ to $75 \%$ of imports of candidate and acceding countries come from future EU countries.

In most CEE countries, the location of the textile industry does not depend on the raw material base. Raw materials used in the textile industry, such as cotton, silk, wool and jute, are imported. They are mainly produced in China, India, USA, Russia and Egypt (cotton and wool) and Italy or Japan (wool). In addition, the industry uses cotton from Kazakhstan, wool from New Zealand and silk from China. The location of enterprises is to a certain extent influenced by the traditions of craft fabric production and presence of cheap labor resources. The fibres and textile industry is often located in industrial districts and large cities because it is very labor intensive and its production is profitable only on a large-scale production. Factories of light industry sectors, in particular clothing, knitting and leather, were also located in centers where other industries offered jobs mainly for men (e.g. in Poland in Ostrowiec Świętokrzyski, Turek, Płock and Puławy). This made it possible to utilize the surpluses of the female workforce there.

The textile industry is currently experiencing a clear crisis, falling exports and competition from cheap imported goods (mainly from East Asia). This resulted in the liquidation of many plants. In the last decade, the share of textiles in the sold production of the industry dropped to almost $1.6 \%$. It is worth mentioning that what has been "left" from the textile industry must be produced of relatively high quality. 


\subsection{Satisfaction of SMEs Employees}

Researchers' interest in employee satisfaction dates back to the 1930s. This issue still intrigues especially representatives of management sciences, sociologists and psychologists. It is even recognized that there is a renaissance of interest in this issue (Juchnowicz, 2014, p.11).

The category of job satisfaction is a concept that can be interpreted from different perspectives. Most often, professional satisfaction is understood as positive feelings and attitudes of a man towards his work environment and professional duties (Staples and Higgins, 1998, p. 213). V.H. Vroom (1964) defines satisfaction as a positive attitude towards work. In turn, for E.A. Locke (1976, p. 1319), job satisfaction is the result of perceiving one's own work as something that enables achieving important values provided that they are compatible with human needs or help to achieve them. Wexley and Yukl (1984) believe that satisfaction is a set of employee feelings and attitudes towards work. Czarnota-Bojarska (2010, p. 51) also indicates that it is an emotional relationship with the employing organization, tasks performed at work and other aspects relevant to professional and social functioning, i.e. a subjective assessment of positive and negative feelings and attitudes of the employee in relation to his professional duties. In other words, a feeling of professional satisfaction is a positive concept which is subjectively conditioned. Thus, satisfaction is a result of the difference between what an employee receives at work and what he thinks he should receive (Hellriegel et al., 1995, p. 12).

Provided that job satisfaction is an element of attitude, it can be assumed that it is a construct composed of three elements: emotional, behavioral and cognitive. They interact with each other, while the employee develops a number of partial attitudes which consequently determine his behavior (Lindzey and Aronson, 1985, p. 233) and overall subjective well-being perception via links between satisfaction with working conditions (Cannas et al., 2019; Faggianelli et al., 2018; Mishchuk \& Grishnova, 2015). Ilies and Judge (2004, p. 367) believe that from the point of view of professional satisfaction, a key component is the emotional part related to the worker's assessment of work.

In the literature on the subject one can find many models of shaping job satisfaction (Jeremiah, Rust \& Martin, 2019; Wijaya, 2019; Ensour, W., Zeglat, D. \& Shrafat, F., 2018; Zahed, A., and Ardabili, F. S. (2017). Most of them have a character of attribute models in which sets of factors affecting job satisfaction are presented, including attitude towards future employer attractiveness (Babikova \& Bucek, 2019). The concept of Vroom (quoted in Sikora, 2000, p. 37), who considered professional satisfaction as a consequence of the expected reward's value, perception of the success probability, efforts put into achieving the assumed result, assessment of the justness of the prize received and comparison of the prize with social standards, has become the basis for many analyzes of factors determining job satisfaction.

Locke (1976) and Springer (2011, p. 166) mentioned the following factors influencing job satisfaction: work that is an intellectual challenge for the employee to cope with, coherence of one's purpose with the organization's goals, physical working conditions consistent with the needs of the employee enabling goal achievement, fair remuneration adequate to individual aspirations, lack of excessive physical overload, giving respect to some employees of the organization, as well as support to combine individual and professional goals along with the support to minimize conflict and ambiguity of roles.

Other studies, in turn, highlight that employee satisfaction benefits from such factors as employee autonomy, challenging work, results, feedback related to supervisor results, work measures and work stability (security) (Vlosky \& Aguilar, 2009, p.1-5).

Bugdol (2006, pp. 155-164) claims that in a professional environment satisfaction can be derived from pay and incentive systems, relations with supervisors and co-workers, market 
position of the company, opinions about the organization expressed by other people as well as the organization itself and nature of work.

Lewicka (2010, p. 65), in turn, points out three groups of factors that affect employee satisfaction to varying degrees. The first group consists of motivating procedures, superiorsubordinate relations and knowledge sharing in the organization. The second group comprises training and development policy, employee evaluation, a sense of subjectivity and quality of communication in the organization. The third group includes effectiveness of recruitment and selection procedures, legibility of responsibilities, diversity management, anti-discrimination and conflict resolution.

According to a different approach, there are three basic groups among satisfaction factors: organizational, social and personal (Gros, 2012, pp. 115-116). Organizational factors are directly related to work. These include the type of tasks performed by the employee (e.g. their level of difficulty), pay (it should be adequate to the employee's obligations and his involvement), promotion prospects, work safety, organization's functioning policy (taking care of employees and their needs) and policy of organization development. Social factors include determinants that refer to the following: organizational climate (an organization should create a good working climate), mutual respect (no criticism of people, listening to each other, respecting each others' views), arrangements with superiors and colleagues (there should be a desire to bring help, mutual friendliness) and customer relations. In turn, personal factors involve workers' individual characteristics that a company has no influence on. These include individual properties, such as age, gender, race, intelligence, use of skills and professional experience at work (Schultz and Schultz, 2008, p. 300).

Lumley et al. (2011, p. 103), on the other hand, indicate nine aspects of job satisfaction: pay (satisfaction with pay and remuneration rises), promotion (satisfaction with the possibility of promotion, i.e. personal development, greater responsibility, higher social status), supervision (satisfaction with a person's direct supervision), benefits (satisfaction with monetary and non-monetary benefits), conditional rewards (satisfaction with recognition and rewards for good work), operational procedures (satisfaction with operational rules and procedures) and colleagues (satisfaction with one's relationships at work). People feel job satisfaction when: they feel that they are able to properly perform their tasks; they realize they are making progress at work; they are employed on favorable terms; they receive support from their colleagues and work environment (having a positive impact on the atmosphere in the organization). Quite important is also one's commitment to work. Those involved to a greater extent feel they are part of the team and are ready to make intensified efforts to achieve their team's goals (Abun et al., 2019, p. 310).

Numerous research works focus on the internal aspect of job satisfaction. The results show a positive relationship between work environment and job satisfaction that is affected by physical working conditions and social working conditions (Sousa-Poza \& Sousa-Poza, 2000; Gazioglu \& Tanselb, 2006; Skalli et al., 2008). Also, according to the recent research by Raziq and Maulabakhsh (2015, pp. 717-725), work environment has a particularly positive impact on employee satisfaction. An important role in shaping a positive work environment is played by the employee satisfaction with remuneration (DeVaney \& Chen, 2003, p. 2). According to the report Employee Job Satisfaction and Engagement: The Doors of Opportunity Are Open (SHRM, 2017, s. 9), this is one of the most important elements of job satisfaction. Davis (2004, p. 495) believes that SME employee remuneration is correlated with job satisfaction but proper management supervision is more important. Interestingly, despite this popular view in the literature, there are also different opinions. For instance, studies conducted by Judge et al. (2010, pp. 157-167) indicate that the level of remuneration is only slightly correlated with job satisfaction. According to the authors, a tendency to 
overestimate the importance of remuneration by employees may lead to the fact that they will not value other factors, e.g. pay equity or its connection with the effort they put into work.

The success of SMEs depends on the employees who are their most valuable capital (Dzieńdziora, 2010, p. 35). That is why in this type of companies job satisfaction is an extremely important issue. Literature suggests that in SMEs, it is important for job satisfaction to provide employees with training, which enables them to broaden their knowledge and be more creative and effective in achieving individual development (Jun, et al., 2006, pp. 791-812). On the other hand, the involvement of employees in the organization leads to their satisfaction which builds organizational efficiency (Hanaysha, 2016, pp. 298306). Singh's (2017, pp. 20-30) research indicates that there is a causal relationship between job satisfaction and employee involvement. In turn, work planning is the factor that causes dissatisfaction. Employees seem confused if they do not know what they are doing or what their career goals are. If employees know what is expected of them, they can easily achieve their goals (Weiss, 2002, pp. 173-194). Defining responsibilities of each employee is therefore a key step to their satisfaction. Workers' performance and results should also be assessed, e.g. every six months or once a year. It is recommended that policies and procedures regarding remuneration and incentives be checked to ensure fairness, which in turn can be more important factor as the level of salary (Mishchuk et al., 2019). In the case of SMEs, it is proposed that management maintains the achieved level of satisfaction or strives for a higher one without allowing its lowering.

By eliminating adverse working conditions, employees can be influenced to make better use of their capabilities and potential. That is why, especially for SMEs, it is important to recognize the importance of a good working environment. This need is all the more essential in the context of the study results (Vladimirova, 2008) which indicate that SME employees express a high level of satisfaction with the possibility of flexible working time and using their initiative and are the least satisfied with their salary and promotion prospects. A higher level of SME employee satisfaction is associated with a lower risk of their leaving the company (Basma et al., 2017, p. 6).

For SMEs, the importance of a working environment in which employees are part of the overall decision-making process becomes particularly important. Flexible working hours, less workload, the right approach to teamwork and management support have a positive impact on the employee performance. This leads to a high level of employee satisfaction, thanks to which staff can become more involved in the company's activities, more motivated to work harder and more willing to work more efficiently, which can bring benefits to their enterprises in the long run. Thus, job satisfaction in SMEs has a direct and positive impact on internal entrepreneurship (Sehunoe et al., 2015, p. 123).

The above-presented factors presented are important when assessing work situations. Constant and regular monitoring of the level of professional satisfaction improves cooperation and communication within the organization. As a result, one can expect a reduced level of rotation and absenteeism as well as an increased level of employee loyalty and morale. This increases a manner of employee engagement and improves the quality and efficiency of their work. According to Reijseger et al. (2017, pp. 117-130), the more employees were involved, the higher their work efficiency was.

Summing up the above considerations, it should be pointed out that there is a strong relationship between employee satisfaction and the effects of the activities of each organization (including SMEs). Professional satisfaction translates into workers' commitment, loyalty, trust in the organization, clients' satisfaction and creativity and innovation which, in turn, leads to better results for the entire organization. 


\subsection{Social capital in SMEs in CEE countries}

The term "social capital" appeared in the sixties. It refers to symbolic common goods of the society that promote the development of social trust and reciprocity standards which, in turn, leads to more effective forms of organization. It includes features of the organization that facilitate coordination of activities, namely: networks, standards, level of trust and cooperation to achieve mutual benefits (Putnam, 1995, p. 14). Therefore, social capital has necessary values for broad development.

The concept of social capital has not come to a universally accepted definition or coherent interpretation. Analyzing numerous definitions of social capital, one can notice a variety of approaches to this issue: from macro-level (e.g. Fukuyama 2003, s. 169), through meso-level (e.g. Coleman, 1990, pp. 317-318) to micro-level (e.g. Bourdieu, 1986, pp. 241258). This category is also analyzed in various concepts (structural, i.e. concerning the network of relationships, normative, i.e. focused on norms and values, and behavioral, i.e. analyzing specific manifestations of behavior). Contemporary scholars also point out an institutional approach to social capital research (e.g. Sandal, 2017, p. 23; Sandal et al., 2019, p. 69).

Therefore, social capital can be seen as the ability to work together within groups and organizations to pursue common interests (Sułkowski, 2017, p. 155). Hence, social capital includes, among others, the quality of relations between the community members, their attitudes and synergy effects. Thus, trust and shared values of members of a given community constitute an important feature of social capital (Sierocińska, 2011, p. 70).

From the point of view of management efficiency, forms of social capital are an important issue. Among them, the aspect of creating an organization based on cooperation deserves close attention. These forms can be classified by assigning them specific elements, such as (Glover \& Hemingway, 2005, p. 391): obligations and expectations, authoritarian relations, information potential, norms and sanctions, purposeful organizations and proper social organization.

Therefore, social capital is a category whose advantages are not limited only to economic effects. They extend to the broadly understood quality of social life. Research results (Skrodzka, 2018, pp. 841-858) have shown that there is a very strong and positive correlation between social capital of the EU countries and the level of their intelligent growth. In addition, research results have identified key aspects of social capital which include collaboration between organizations.

When analyzing social capital, negative aspects should also be taken into consideration. Among them, there are obstacles to innovation caused by rigid standards in force in a given group, costs of lost opportunities arising from a chance for economic activity outside a given connection network, high costs of investing in relationships within the network or costs for people outside the group resulting from collusion (Raczkowska, 2009, p. 44). Due to these factors, the term "negative social capital" has appeared in the literature on the subject. Portes (1998, pp. 15-17) presents four manifestations of this phenomenon: exclusion, which means that only members of the distinguished social group are admitted to goods (material values, positions or privileges), pressure put by certain social groups on excessive benefits, reducing opportunities for the development of others, limiting freedom of the individuals and lowering the requirements related to social behavior, dictated by the distortion of rules.

There are many different forms of social capital but one, rather simple, approach divides them into three main categories (Keeley, 2017, p. 102):

- Bonding capital: a connection based on the sense of the shared identity ("people like us"), such as family, close friends and people who share our culture or ethnicity. 
- Bridge capital: relationships that go beyond a shared sense of identity, for example, distant friends, colleagues or peers.

- Relationship capital: it refers to individuals or groups in the hierarchy of the social ladder.

Difficulties with clearly defining a semantic scope of social capital bring problems with measuring this phenomenon and comparing research results. The basic components of social capital (in the broad sense, measured at a macro level) include three aspects which are a starting point for the construction of many measures of this capital, namely: the structural element, i.e. social networks, groups, structures and social institutions, information channels, connections; regulatory element (cognitive social capital), i.e. social norms, especially those relating to cooperation as well as patterns of realizing values and interests, trust, solidarity, custom and customs; behavioral element, which refers to specific manifestations of interaction, i.e. cooperation, help, volunteering, collective actions and information exchange (Markowska-Przybyła \& Ramsey 2017, p. 13). However, this element is not present in all analyses because it is not clear whether to treat it as a component of social capital or as an indicator of external correlation. Social capital is not a tangible value. Therefore, it is difficult to measure and evaluate it in numerical values. In addition to local historical and cultural influences, social consensus in society is influenced by several factors: health care systems and their universal access to protect health; equality of income and assets that are correlated with crime levels; demographic structure (to assess future generational balance in society); freedom of speech, freedom from fear and lack of violent conflicts. These factors are required so that companies can generate value. Various organizations measure social capital in individual countries around the world. Social capital is one of the elements of the indices they measure. According to the report The Global Sustainable Competitiveness Index (SolAbility, 2017, p. 41), the average index of social capital in the world in 2017 amounted to 46.7, while the maximum level reached 63.2, and the minimum level was 29.1. Table 3 presents the social capital index level in individual CEE countries in 2017. Among these countries, the highest level of social capital in 2017 was in by Latvia which took 15th place in the world. Bulgaria was the worst in this respect (159th place). Thus, CEE countries are lagging behind in terms of social capital.

Table 3. Index of social capital in individual CEE countries in 2017 according to SolAbility

\begin{tabular}{lcc}
\hline Countries & Social capital index & Position in the world \\
\hline Latvia & 56.7 & 15 \\
\hline Croatia & 55.8 & 19 \\
\hline Slovakia & 55.3 & 20 \\
\hline Lithuania & 53.5 & 25 \\
\hline Romania & 52.4 & 35 \\
\hline Czech Republic & 50.3 & 59 \\
\hline Poland & 48.1 & 74 \\
\hline Slovenia & 46.3 & 93 \\
\hline Hungary & 44.1 & 117 \\
\hline Estonia & 42.2 & 131 \\
\hline Bulgaria & 37.7 & 159 \\
\hline
\end{tabular}

Source: study based on SolAbility (2017. p. 41).

In 2018, social capital was examined by the World Economic Forum in the context of personal quality and social relations, strength of social norms and level of civic participation in society. The authors of the ranking assumed that social capital creates greater cohesion in 
society and trust between people, thereby reducing transaction costs. Social capital was also included in the survey of the so-called Legatum Prosperity Index 2018 (Legatum Institute 2018) where social capital measures the strength of personal relationships, social network support, social norms and civic participation in a given country. Table 4 presents the social capital index in 2018.

Table 4. Index of social capital in individual CEE countries in 2018 according to the World Economic Forum and according to the Legatum Institute

\begin{tabular}{lcccc}
\hline Countries & \multicolumn{2}{c}{ World Economic Forum } & \multicolumn{2}{c}{ Legatum Institute } \\
\cline { 2 - 5 } & $\begin{array}{c}\text { Social Capital } \\
\text { Index }\end{array}$ & $\begin{array}{c}\text { Place in the } \\
\text { world }\end{array}$ & $\begin{array}{c}\text { Social Capital } \\
\text { Index }\end{array}$ & $\begin{array}{c}\text { Place in the } \\
\text { world }\end{array}$ \\
\hline Slovenia & 58.4 & 24 & 60.06 & 20 \\
\hline Estonia & 51.9 & 58 & 51.08 & 69 \\
\hline Slovakia & 51.4 & 63 & 52.19 & 59 \\
\hline Czech Republic & 50.1 & 69 & 49.96 & 71 \\
\hline Poland & 50.1 & 70 & 49.45 & 76 \\
\hline Romania & 49.7 & 77 & 48.70 & 77 \\
\hline Hungary & 48.7 & 87 & 49.44 & 113 \\
\hline Latvia & 46.7 & 99 & 45.50 & 85 \\
\hline Bulgaria & 46.1 & 102 & 48.55 & 98 \\
\hline Croatia & 44.6 & 112 & 45.90 & 109 \\
\hline Lithuania & 42.2 & 121 & 46.98 & \\
\hline
\end{tabular}

Source: elaboration based on data from the site: https://www.prosperity.com/rankings $(2 / 04 / 2019)$

It should be noted, however, that despite the elaboration of aggregate rankings for countries, the level of social capital in individual countries may vary in specific regions.

For example, in Slovenia, social capital consists of cooperation networks based on regular face-to-face meetings, standards and trust. Research by Potočnik Slavič (2009, pp. 2136) (based on the official data and field studies of the associations at the municipal level) in Slovenian rural areas showed that local associations are an important factor for local development and a tool for measuring social capital development. Based on the analyses, the following types of social capital organization were defined: hierarchical organization (Suha krajina), bridging organization (Upper Savinja Valley) and concentric organization (Goriška brda). Economically and demographically eroded areas have few elements of social capital. As a result, they are not prospective for local development (for example, Brkini).

Similarly, in Poland, social capital resources differ significantly in individual regions. For example, western and northern regions in most cases show a higher than average level of bridge social capital although one can notice significant variation in them. Empirical findings indicate that, for example, Wielkopolska (Poznań region) has a generally low level of bridge social capital and bonding capital. In this respect, it is similar to the central areas of Poland (Czapiński \& Panek 2015).

SMEs usually rely on local social capital. Managers use close relationships because they associate them with higher levels of trust. In other words, they perceive such ties as more credible, which results in better information and organization. Research results suggest that such close social ties may hinder early internationalization of SMEs. Rather, these companies tend to focus on a limited number of foreign partners and neglect to build new relationships that could help them in their future challenges. In addition, companies that significantly rely 
on close relationships can be isolated from other valuable sources of information. Thirdly, a high level of trust in close relationships can lead to limited information processing. As a result, the company is not focused on the best opportunities (Musteen et al., 2010, p. 198). Dependence on one foreign collaborator and, therefore, a lack of social capital is one of the biggest threats to SMEs which desire to enter foreign markets.

To sum up, social capital plays a huge role for the development of knowledge and innovation. It is also important for economic growth. In individual countries, its resources are not uniform and its measurement is not easy due to the need to take into account many qualitative elements, including satisfaction.

\section{Methodological approach}

\subsection{Hypotheses}

The following question was asked as a research question: What are the main factors affecting employee satisfaction of SMEs in the fibres and textile industry in the CEE countries?

The following research hypothesis was put forward: Hypothesis 1. The level of employee satisfaction working for fibres and textiles SMEs in Central and Eastern Europe depends on the level of social capital.

\subsection{Methods}

The purpose of this study is an attempt to identify determinants affecting professional satisfaction of employees of small and medium-sized enterprises in the fibres and textile industry in the CEE countries.

The research results presented in this study were obtained after the implementation of a research project carried out in the period from February to May 2019. The project investigated employee satisfaction of small and medium-sized enterprises. The research was conducted in four countries belonging to the CEE countries, i.e. Poland, the Czech Republic, Slovakia and Lithuania. The empirical research was quantitative. The use of the survey questionnaire as a research tool allowed for a percentage summary of the collected responses based on subjective opinions of the respondents covered by the survey.

For the purposes of this study, enterprises operating in the fibres and textile industry have been identified. Detailed characteristics describing the test sample are presented in Table 5.

While assessing the factors affecting job satisfaction, relationships in the company, communication, systems of remuneration and motivating employees as well as a feeling of constancy and employment stability were analyzed. The Pearson's chi-square, the likelihood ratio and the linear relationship test were applied in order to determine the interdependence between an employee's country of residence and the specified factors of job satisfaction. 
Table 5. Characteristics of the research sample

\begin{tabular}{|c|c|c|}
\hline \multicolumn{3}{|c|}{ research sample = $295(100 \%)$} \\
\hline \multicolumn{3}{|c|}{ Characteristics describing respondents participating in the survey: } \\
\hline \multirow[t]{2}{*}{ sex of respondents } & Women & $29.5 \%$ \\
\hline & Men & $69.5 \%$ \\
\hline \multirow[t]{5}{*}{ age of respondents } & up to 25 years old & $12.2 \%$ \\
\hline & 26-35 years old & $10.8 \%$ \\
\hline & $36-45$ years old & $31.2 \%$ \\
\hline & $46-55$ years old & $36.6 \%$ \\
\hline & over 55 years old & $9.2 \%$ \\
\hline \multirow[t]{3}{*}{ education of respondents } & Higher & $32.5 \%$ \\
\hline & Secondary & $41.4 \%$ \\
\hline & Vocational & $26.1 \%$ \\
\hline \multirow[t]{5}{*}{ seniority } & up to 5 years & $12.2 \%$ \\
\hline & $5-10$ years & $16.6 \%$ \\
\hline & 11-20 years & $43.1 \%$ \\
\hline & 21-30 years & $19.0 \%$ \\
\hline & over 30 years & $9.2 \%$ \\
\hline \multirow[t]{2}{*}{ position held } & Executive & $16.6 \%$ \\
\hline & Managerial & $83.4 \%$ \\
\hline \multicolumn{3}{|c|}{ Characteristics describing enterprises covered by the survey: } \\
\hline \multirow[t]{3}{*}{ company size by number of employees } & micro-enterprise (0-9) & $42.0 \%$ \\
\hline & small enterprise (10-49) & $47.8 \%$ \\
\hline & medium enterprise (50-249) & $10.2 \%$ \\
\hline \multirow[t]{4}{*}{ country of the company activity } & Poland & $32.2 \%$ \\
\hline & Lithuania & $19.3 \%$ \\
\hline & The Czech Republic & $21.4 \%$ \\
\hline & Slovakia & $27.1 \%$ \\
\hline
\end{tabular}

Source: Own study.

\section{Results and Discussion}

At the beginning of the survey, respondents were asked if they felt satisfied with their work. As many as $74.9 \%$ of the surveyed employees of the fibres and textile industry indicated 'yes' and 'rather yes', as shown in Figure 4.

The issues related to job satisfaction in individual countries in which the research was conducted are presented in Table 6. There was a relationship between employee satisfaction with their work and the country of their residence $(\mathrm{P}=0.009)$. The most positive answers were given by the inhabitants of Slovakia (78.8\% answered 'rather yes", $8.8 \%$ - 'yes'). The Czech Republic came second with $78.5 \%$ positive responses. Poland took third place. Lithuanians were the least satisfied with their work.

Taking into account the social capital index values for the analyzed countries (Table 4 ), it should be noted that the share of positive responses regarding satisfaction with work corresponded with the social capital index. It can therefore be concluded that the degree of textile workers' satisfaction with work is correlated with the social capital index value. 
Therefore, the $\mathrm{H} 1$ hypothesis has been confirmed. Table 7 shows the Chi-square tests which show a significant relationship between the country of residence and employee satisfaction.

Respondents were also asked if they felt satisfaction with various aspects of their work. The assessment included relations prevailing in the company, communication, remuneration systems, motivating employees and a sense of consistency and stability of employment.

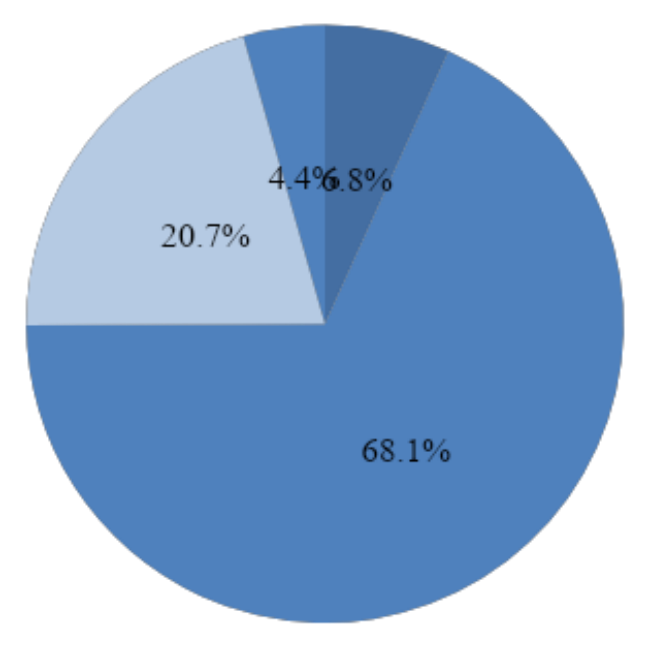

Yes $\square$ Rather yes $\square$ Rather no $\square$ No

Figure 4. Satisfaction with the work performed Source: own study.

Table 6. Satisfaction with work performed in individual countries

\begin{tabular}{lrrrrr}
\hline Responses & $\begin{array}{c}\text { The Czech } \\
\text { Republic }\end{array}$ & Lithuania & \multicolumn{1}{c}{ Poland } & Slovakia & Altogether \\
\hline Yes & $10.8 \%$ & $1.8 \%$ & $5.3 \%$ & $8.8 \%$ & $6.8 \%$ \\
\hline rather yes & $67.7 \%$ & $55.4 \%$ & $67.0 \%$ & $78.8 \%$ & $68.1 \%$ \\
\hline rather no & $15.4 \%$ & $33.9 \%$ & $24.5 \%$ & $11.3 \%$ & $20.7 \%$ \\
\hline No & $6.2 \%$ & $8.9 \%$ & $3.2 \%$ & $1.3 \%$ & $4.4 \%$ \\
\hline Altogether & $100.0 \%$ & $100.0 \%$ & $100.0 \%$ & $100.0 \%$ & $100.0 \%$ \\
\hline
\end{tabular}

Source: own study.

Table 7. Values of selected tests of the relationship between the country of residence and satisfaction with the work performed

\begin{tabular}{lccc}
\hline \multicolumn{1}{c}{ Test } & Value & df & $\begin{array}{c}\text { Asymptotic } \\
\text { significance (two- } \\
\text { sided) }\end{array}$ \\
\hline Pearson's chi-square & 21.924 & 9 & .009 \\
\hline Likelihood ratio & 22.634 & 9 & .007 \\
\hline Linear relationship test & 3.353 & 1 & .067 \\
\hline N of important observations & 295 & & \\
\hline
\end{tabular}

Source: own study. 
Relationships in the company were similarly positively assessed by the employees (Fig. 5). As many as $71.9 \%$ of the surveyed evaluated these relations in a positive way.
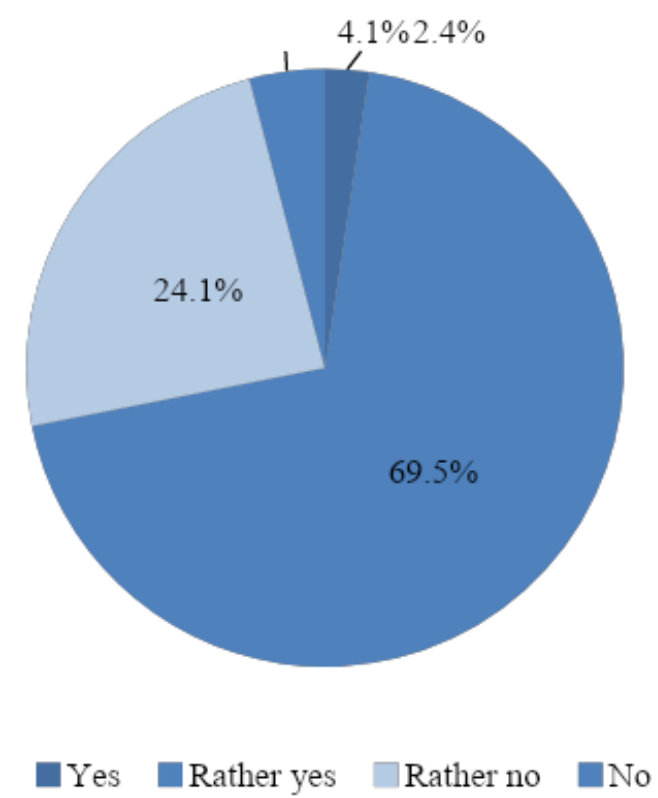

Figure 5. Satisfaction with relations prevailing in the company

Source: own study.

There was a relationship between the assessment of satisfaction with the relations prevailing in the company and the country of residence $(\mathrm{P}=0.000)$. The most positive answers were given by the inhabitants of Slovakia (91.3\% - rather yes and $2.5 \%$ - yes). The Czech Republic came second with $83.1 \%$ positive responses. Poland took third place. The residents of Lithuania were the least satisfied with the relations prevailing in the employment company, as shown in Table 8.

Table 8. Satisfaction with relations prevailing in the company in individual countries

\begin{tabular}{lrrrrr}
\hline Responses & $\begin{array}{c}\text { The Czech } \\
\text { Republic }\end{array}$ & Lithuania & \multicolumn{1}{c}{ Poland } & Slovakia & Altogether \\
\hline Yes & $3.1 \%$ & & $3.2 \%$ & $2.5 \%$ & $2.4 \%$ \\
\hline Rather yes & $80.0 \%$ & $42.9 \%$ & $59.6 \%$ & $91.3 \%$ & $69.5 \%$ \\
\hline Rather no & $16.9 \%$ & $44.6 \%$ & $33.0 \%$ & $5.0 \%$ & $24.1 \%$ \\
\hline No & & $12.5 \%$ & $4.3 \%$ & $1.3 \%$ & $4.1 \%$ \\
\hline Altogether & $100.0 \%$ & $100.0 \%$ & $100.0 \%$ & $100.0 \%$ & $100.0 \%$ \\
\hline
\end{tabular}

Source: own study.

Considering the test values (Table 9), it can be concluded that the degree of satisfaction with the relationships prevailing in the company textile workers work for shows a significant dependence.

Another examined issue affecting job satisfaction was employee satisfaction with communication in the company (Fig. 6).

Satisfaction with communication in the company in individual countries is presented in Table 10. The most positive answers were given by employees in Slovakia (9.3\%) and the Czech Republic (84.6\%). Employees from Poland came third (61.7\%). Employees from Lithuania came fourth (42.9\%). Considering the test values (Table 11), it should be assumed 
that the degree of satisfaction with communication in the company textile workers work for shows a significant relationship.

Table 9. Values of selected tests of the relationship of the country of residence and satisfaction with the relations prevailing in the company

\begin{tabular}{lccc}
\hline \multicolumn{1}{c}{ Test } & Value & df & $\begin{array}{c}\text { Asymptotic } \\
\text { significance (two- } \\
\text { sided) }\end{array}$ \\
\hline Pearson's chi-square & 55.683 & 9 & .000 \\
\hline Likelihood ratio & 60.814 & 9 & .000 \\
\hline Linear relationship test & 3.764 & 1 & .052 \\
\hline N of important observations & 295 & & \\
\hline
\end{tabular}

Source: own study.

Another issue raised in the study was employee satisfaction with the incentive systems in force in the company they work for (Fig. 7). Employees in the fibres and textile industry are not satisfied with motivation systems. As many as $86.8 \%$ of the surveyed responded negatively. There were only $4.4 \%$ positive responses in this case.

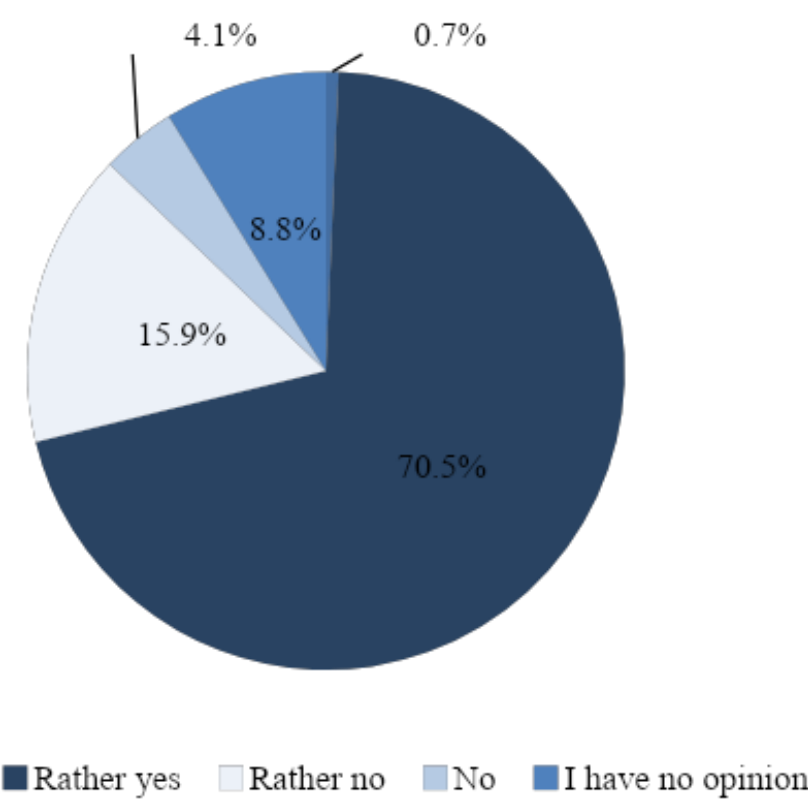

Figure 6. Satisfaction with communication in the company

Source: own study.

Table 10. Satisfaction with communication in the company in individual countries

\begin{tabular}{lrrrrr}
\hline Responses & $\begin{array}{c}\text { The Czech } \\
\text { Republic }\end{array}$ & Lithuania & Poland & Slovakia & Altogether \\
\hline yes & $3.1 \%$ & & & & $0.7 \%$ \\
\hline rather yes & $81.5 \%$ & $42.9 \%$ & $61.7 \%$ & $91.3 \%$ & $70.5 \%$ \\
\hline rather no & $10.8 \%$ & $26.8 \%$ & $21.3 \%$ & $6.3 \%$ & $15.9 \%$ \\
\hline No & & $12.5 \%$ & $4.3 \%$ & $1.3 \%$ & $4.1 \%$ \\
\hline I have no opinion & $4.6 \%$ & $17.9 \%$ & $12.8 \%$ & $1.3 \%$ & $8.8 \%$ \\
\hline Altogether & $100.0 \%$ & $100.0 \%$ & $100.0 \%$ & $100.0 \%$ & $100.0 \%$ \\
\hline
\end{tabular}

Source: own study. 
Table 11. Values of selected tests of the relationship of the country of residence and satisfaction with communication in the company

\begin{tabular}{lccc}
\hline \multicolumn{1}{c}{ Test } & Value & df & $\begin{array}{c}\text { Asymptotic } \\
\text { significance (two- } \\
\text { sided) }\end{array}$ \\
\hline Pearson's chi-square & 59.164 & 12 & .000 \\
\hline Likelihood ratio & 60.992 & 12 & .000 \\
\hline Linear relationship test & 1.863 & 1 & .172 \\
\hline N of important observations & 295 & & \\
\hline
\end{tabular}

Source: own study.

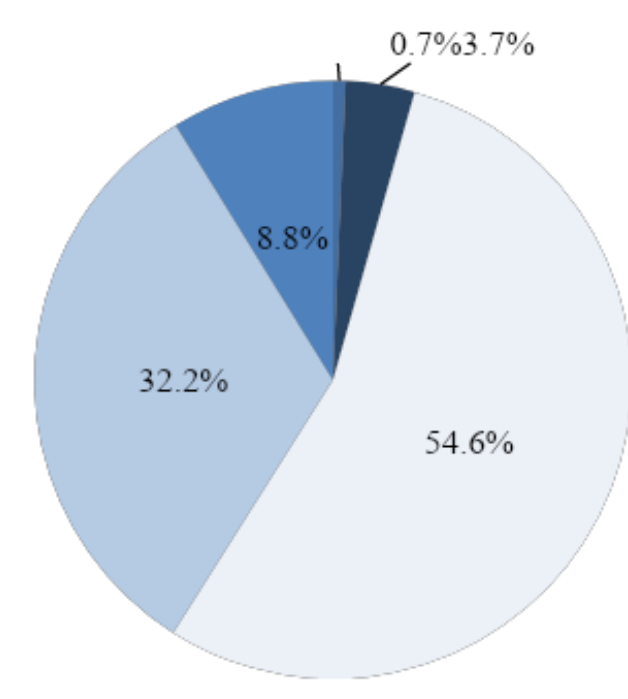

Yes $\square$ Rather yes $\square$ Rather no $\square$ No $\square$ I have no opinion

Figure 7. Satisfaction with incentive systems in force in the company

Source: own study.

Satisfaction of employees of the fibres and textile industry with incentive systems in force in the company they work for differed in individual countries (Table 12). Slovak employees were the most dissatisfied with the motivation systems $(92.5 \%) .87 .7 \%$ of those surveyed indicated dissatisfaction in the Czech Republic, $84.1 \%$ in Poland and $82.2 \%$ in Lithuania. At the same time, in Lithuania and Poland one can notice a relatively smallest percentage of people who indicated satisfaction. Considering the test values (Table 13), the relationship can be considered to be statistically significant.

Satisfaction of the surveyed employees with the applicable remuneration systems was at a slightly higher level than in the case of satisfaction with motivation systems (Fig. 8). In this case, positive responses constituted $20.0 \%$, which indicates significant dissatisfaction with the remuneration systems of SME employees in the fibres and textile industry. 
Table 12. Satisfaction with the incentive systems in force in company in individual countries

\begin{tabular}{lrrrrr}
\hline Responses & $\begin{array}{c}\text { The Czech } \\
\text { Republic }\end{array}$ & Lithuania & \multicolumn{1}{c}{ Poland } & Slovakia & Altogether \\
\hline yes & & & & $2.5 \%$ & $0.7 \%$ \\
\hline rather yes & $7.7 \%$ & & $3.2 \%$ & $3.8 \%$ & $3.7 \%$ \\
\hline rather no & $69.2 \%$ & $26.8 \%$ & $39.4 \%$ & $80.0 \%$ & $54.6 \%$ \\
\hline No & $18.5 \%$ & $55.4 \%$ & $44.7 \%$ & $12.5 \%$ & $32.2 \%$ \\
\hline I have no opinion & $4.6 \%$ & $17.9 \%$ & $12.8 \%$ & $1.3 \%$ & $8.8 \%$ \\
\hline Altogether & $100.0 \%$ & $100.0 \%$ & $100.0 \%$ & $100.0 \%$ & $100.0 \%$ \\
\hline
\end{tabular}

Source: own study.

The greatest satisfaction with the remuneration systems in force in the company was indicated by Czech employees (29.2\%) and Slovak employees $(22.5 \%)$. In the case of Polish employees, this satisfaction was at the level of $19.1 \%$. In the case of Lithuanian employees, it reached the level of $7.1 \%$ (Table 14). Considering the test values (Table 15), it can be concluded that the relationship is statistically significant.

Table 13. Values of selected tests of the relationship of the country of residence and satisfaction with the incentive systems in force in the company

\begin{tabular}{lccc}
\hline \multicolumn{1}{c}{ Test } & df & $\begin{array}{c}\text { Asymptotic } \\
\text { significance (two- } \\
\text { sided) }\end{array}$ \\
& Value & df & .000 \\
\hline Pearson's chi-square & 74.896 & 12 & .000 \\
\hline Likelihood ratio & 80.424 & 12 & .077 \\
\hline Linear relationship test & 3.120 & 1 & \\
\hline N of important observations & 295 & & \\
\hline
\end{tabular}

Source: own study.

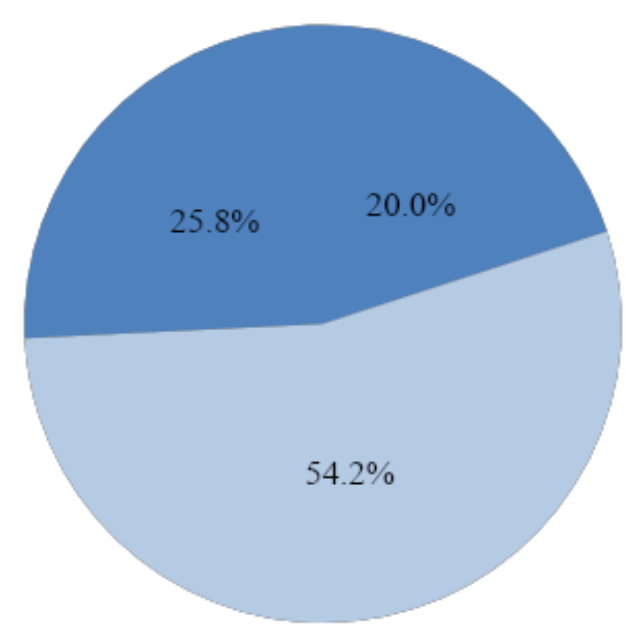

Yes $\square$ Rather yes $\square$ Rather no $\square$ No

Figure 8. Satisfaction with the remuneration systems in force in the company

Source: own study. 
Table 14. Satisfaction with the remuneration systems in force in the company in individual countries

\begin{tabular}{lrrrrr}
\hline Responses & $\begin{array}{c}\text { The Czech } \\
\text { Republic }\end{array}$ & Lithuania & Poland & Slovakia & Altogether \\
\hline yes & & & & & \\
\hline rather yes & $29.2 \%$ & $7.1 \%$ & $19.1 \%$ & $22.5 \%$ & $20.0 \%$ \\
\hline rather no & $60.0 \%$ & $37.5 \%$ & $45.7 \%$ & $71.3 \%$ & $54.2 \%$ \\
\hline No & $10.8 \%$ & $55.4 \%$ & $35.1 \%$ & $6.3 \%$ & $25.8 \%$ \\
\hline Altogether & $100.0 \%$ & $100.0 \%$ & $100.0 \%$ & $100.0 \%$ & $100.0 \%$ \\
\hline
\end{tabular}

Source: own study.

Table 15. Values of selected tests of the relationship of the country of residence and satisfaction with the remuneration systems in force in the company

\begin{tabular}{lccc}
\hline \multicolumn{1}{c}{ Test } & Value & df & $\begin{array}{c}\text { Asymptotic } \\
\text { significance (two- } \\
\text { sided) }\end{array}$ \\
\hline Pearson's chi-square & 56.210 & 6 & .000 \\
\hline Likelihood ratio & 59.164 & 6 & .000 \\
\hline Linear relationship test & .600 & 1 & .439 \\
\hline N of important observations & 295 & & \\
\hline
\end{tabular}

Source: own study.

Another issue raised in the research was employee satisfaction with the remuneration received (Fig. 9). Over half of the surveyed employees are not satisfied (56.9\%) with their salary. Employees from Slovakia (73.2\%) and the Czech Republic (62.8\%) are the most satisfied. In turn, the smallest satisfaction occurs in Poland (23.1\%) and Lithuania (15.0\%), as shown in Table 16.

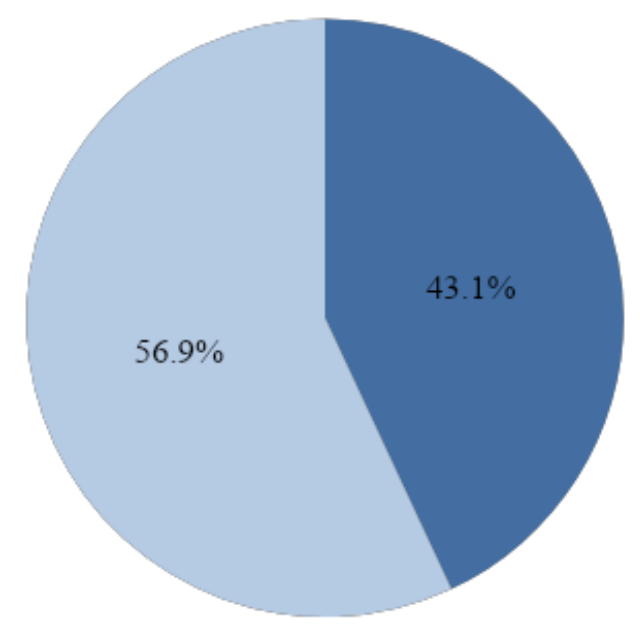

पyes $\square$ No

Figure 9. Employee satisfaction with remuneration received

Source: own study. 
Table 16. Employee satisfaction with remuneration received in individual countries

\begin{tabular}{lrrrrr}
\hline Responses & $\begin{array}{c}\text { The Czech } \\
\text { Republic }\end{array}$ & Lithuania & \multicolumn{1}{c}{ Poland } & \multicolumn{1}{c}{ Slovakia } & \multicolumn{1}{c}{ Altogether } \\
\hline yes & $62.8 \%$ & $15.0 \%$ & $23.1 \%$ & $73.2 \%$ & $43.1 \%$ \\
\hline No & $37.2 \%$ & $85.0 \%$ & $76.9 \%$ & $26.8 \%$ & $56.9 \%$ \\
\hline Altogether & $100.0 \%$ & $100.0 \%$ & $100.0 \%$ & $100.0 \%$ & $100.0 \%$ \\
\hline
\end{tabular}

Source: own study.

Table 17 presents the Chi-square tests which indicate the existence of a significant relationship between the country of residence and satisfaction with the remuneration received by employees.

With regard to remuneration, the surveyed employees were asked to assess it in comparison to other economy sectors (Fig. 10). Most surveyed employees, 53.9\%, indicate that it is at a similar level. Only $18.0 \%$ of respondents point out that it is a higher level.

Table 17. Values of selected tests of the relationship of the country of residence and employee satisfaction with remuneration

\begin{tabular}{lccc}
\hline \multicolumn{1}{c}{ Test } & Value & df & $\begin{array}{c}\text { Asymptotic } \\
\text { significance (two- } \\
\text { sided) }\end{array}$ \\
\hline Pearson's chi-square & 71.936 & 3 & .000 \\
\hline Likelihood ratio & 76.179 & 3 & .000 \\
\hline Linear relationship test & 2.029 & 1 & .154 \\
\hline N of important observations & 295 & & \\
\hline
\end{tabular}

Source: own study.

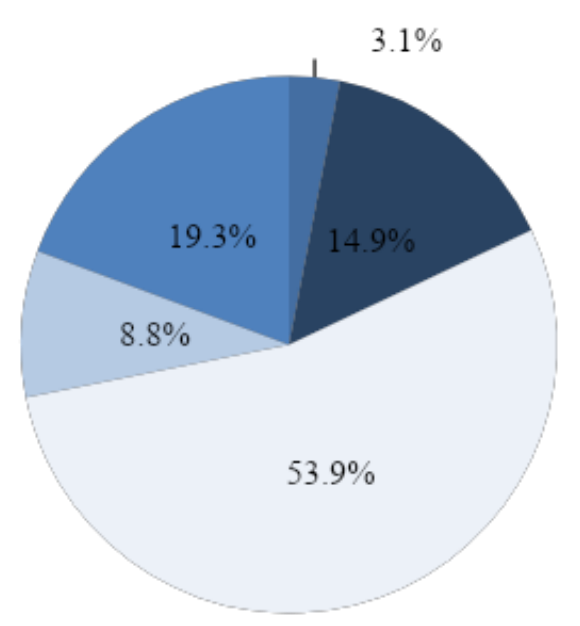

Figure 10. Salary assessment compared to other economy sectors Source: own study. 
The smallest discrepancies between the remuneration of SME employees in the fibres and textile industry and the remuneration in other economy sectors (according to the respondents' subjective assessments) were indicated in Slovakia and the Czech Republic. In this respect, Poland took third place. However, the largest disparities were indicated in Lithuania (Table 18). Taking into account the test values (Table 19), it can be concluded that the relationship is statistically significant.

Table 18. Assessment of remuneration in comparison with other economy sectors in individual countries

\begin{tabular}{lrrrrr}
\hline Responses & $\begin{array}{c}\text { The Czech } \\
\text { Republic }\end{array}$ & Lithuania & Poland & Slovakia & Altogether \\
\hline definitely higher & $6.2 \%$ & $1.8 \%$ & $2.1 \%$ & $2.5 \%$ & $3.1 \%$ \\
\hline rather higher & $9.2 \%$ & $16.1 \%$ & $21.3 \%$ & $11.3 \%$ & $14.9 \%$ \\
\hline at a similar level & $67.7 \%$ & $25.0 \%$ & $39.4 \%$ & $80.0 \%$ & $53.9 \%$ \\
\hline rather lower & $4.6 \%$ & $17.9 \%$ & $12.8 \%$ & $1.3 \%$ & $8.8 \%$ \\
\hline definitely lower & $12.3 \%$ & $39.3 \%$ & $24.5 \%$ & $5.0 \%$ & $19.3 \%$ \\
\hline Altogether & $100.0 \%$ & $100.0 \%$ & $100.0 \%$ & $100.0 \%$ & $100.0 \%$ \\
\hline
\end{tabular}

Source: own study.

Table 19. Values of selected tests of the relationship of the country of residence and the assessment of remuneration in comparison with other economy sectors

\begin{tabular}{lccc}
\hline \multicolumn{1}{c}{ Test } & Value & df & $\begin{array}{c}\text { Asymptotic } \\
\text { significance (two- } \\
\text { sided) }\end{array}$ \\
\hline Pearson's chi-square & 68.528 & 12 & .000 \\
\hline Likelihood ratio & 72.137 & 12 & .000 \\
\hline Linear relationship test & 2.200 & 1 & .138 \\
\hline N of important observations & 295 & & \\
\hline
\end{tabular}

Source: own study.

Workers' feeling of job stability and constancy contributes to their satisfaction. This feeling is very strong among respondents. $81.1 \%$ of the surveyed indicated the presence of this factor in their professional work (Fig. 11).

There was also a relationship between the sense of constancy and stability of employment and the country of residence $(P=0.000)$. Employees from Lithuania felt the safest $(32.1 \%)$, which is illustrated by their positive answers. Almost every fourth employee from Poland was sure of the constancy and stability of their employment (23.4\%). The Czech Republic came third in this respect, followed by Slovakia (Table 20). Taking into account the test values (Table 21), it can be concluded that the relationship is statistically significant.

When considering the social capital index values for the analyzed countries, it should be noted that a number of definitely positive answers regarding the constancy and stability of employment corresponded with the social capital index. The higher the share of people declaring that their employment is more constant and stable, the lower the social capital index. 


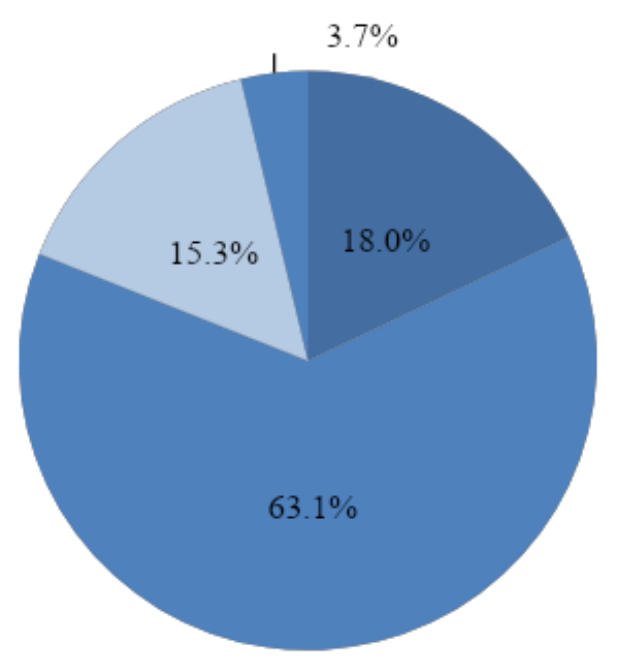

पes $\square$ Rather yes $\square$ Rather no $\square$ No

Figure 11. Workers' feeling of constancy and job stability

Source: own study.

Table 20. Feeling of constancy and employment stability among employees in individual countries

\begin{tabular}{lrrrrr}
\hline Responses & $\begin{array}{c}\text { The Czech } \\
\text { Republic }\end{array}$ & Lithuania & Poland & Slovakia & Altogether \\
\hline Yes & $12.3 \%$ & $32.1 \%$ & $23.4 \%$ & $6.3 \%$ & $18.0 \%$ \\
\hline rather yes & $67.7 \%$ & $46.4 \%$ & $67.0 \%$ & $66.3 \%$ & $63.1 \%$ \\
\hline rather no & $13.8 \%$ & $12.5 \%$ & $7.4 \%$ & $27.5 \%$ & $15.3 \%$ \\
\hline No & $6.2 \%$ & $8.9 \%$ & $2.1 \%$ & & $3.7 \%$ \\
\hline Altogether & $100.0 \%$ & $100.0 \%$ & $100.0 \%$ & $100.0 \%$ & $100.0 \%$ \\
\hline
\end{tabular}

Source: own study.

Table 21. Values of selected tests of the relationship between the country of residence and satisfaction with the relationships prevailing in the company

\begin{tabular}{lccc}
\hline \multicolumn{1}{c}{ Test } & Value & df & $\begin{array}{c}\text { Asymptotic } \\
\text { significance (two- } \\
\text { sided) }\end{array}$ \\
\hline Pearson's chi-square & 38.822 & 9 & .000 \\
\hline Likelihood ratio & 41.099 & 9 & .000 \\
\hline Linear relationship test & .147 & 1 & .701 \\
\hline N of important observations & 295 & & \\
\hline
\end{tabular}

Source: own study.

Despite a strong feeling of constancy and employment stability, just over half of the employees of the fibres and textile industry are considering changing the company they work for (Fig. 12). 


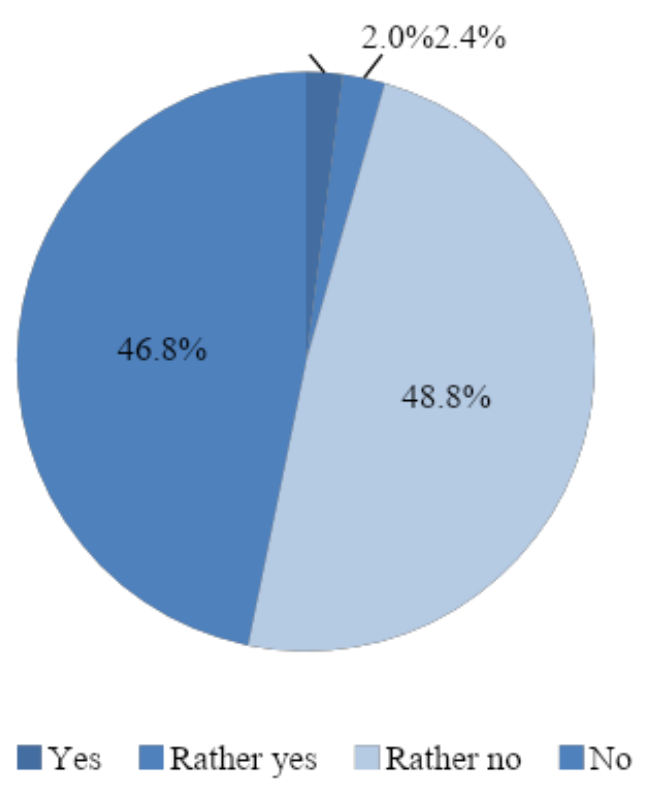

Figure 12. Workers' plans regarding leaving their current company Source: own study.

Relatively fewest employees surveyed have plans to leave their current company in Slovakia (1.3\%) and Poland (3.2\%). The Czech employees came third, with $6.2 \%$ of respondents planning to leave. The largest number of people planning to change their job was recorded in Lithuania (8.9\%), as shown in Table 22. Given the test values (Table 23), it can be concluded that the relationship is statistically significant.

Table 22. Workers' plans to leave their current company in individual countries

\begin{tabular}{lccccc}
\hline Responses & $\begin{array}{c}\text { The Czech } \\
\text { Republic }\end{array}$ & Lithuania & Poland & Slovakia & Altogether \\
\hline Yes & & $7,1 \%$ & $1,1 \%$ & $1,3 \%$ & $2,0 \%$ \\
\hline rather yes & $6,2 \%$ & $1,8 \%$ & $2,1 \%$ & & $2,4 \%$ \\
\hline rather no & $60,0 \%$ & $32,1 \%$ & $44,7 \%$ & $56,3 \%$ & $48,8 \%$ \\
\hline No & $33,8 \%$ & $58,9 \%$ & $52,1 \%$ & $42,5 \%$ & $46,8 \%$ \\
\hline Altogether & $100,0 \%$ & $100,0 \%$ & $100,0 \%$ & $100,0 \%$ & $100,0 \%$ \\
\hline
\end{tabular}

Source: own study.

Table 23. Values of selected tests of the relationship between the country of residence and workers' plans to leave their current company

\begin{tabular}{lccc}
\hline \multicolumn{1}{c}{ Test } & Value & df & $\begin{array}{c}\text { Asymptotic } \\
\text { significance (two- } \\
\text { sided) }\end{array}$ \\
\hline Pearson's chi-square & 26.174 & 9 & .002 \\
\hline Likelihood ratio & 25.865 & 9 & .002 \\
\hline Linear relationship test & 1.479 & 1 & .224 \\
\hline N of important observations & 295 & & \\
\hline
\end{tabular}

Source: own study. 


\section{Conclusion}

Work is a source of satisfaction that triggers creativity and innovation. It motivates employees to learn, develop and improve, which affects the quality of their work and its results. Therefore, care for maintaining professional satisfaction of SME employees at a high level may result in strengthening the employer's role on the market and increasing the company's competitiveness.

The above-presented study attempted to identify determinants affecting professional satisfaction of employees of small and medium-sized enterprises in the fibres and textile industry in the CEE countries.

The study has confirmed that there is a relationship between job satisfaction and workers' country of residence. A number of positive answers regarding satisfaction with work corresponds to the social capital index, which confirms the adopted research assumption.

While assessing the factors affecting job satisfaction, relationships in the company, communication, systems of remuneration and motivating employees as well as a feeling of constancy and employment stability were analyzed. Among them, workers' relations and company communication as well as constancy and stability of employment were positively assessed by the employees. The incentive and remuneration systems in force were evaluated negatively. Every second employee in the surveyed industry indicated a lack of satisfaction with the salary received. The employees from Slovakia and the Czech Republic are the most satisfied. In turn, the lowest satisfaction with the remuneration received can be observed in Poland and Lithuania.

Despite a strong feeling of constancy and employment stability, just over half of the workers employed in the fibres and textile industry are considering changing the company they currently work for.

To sum up, employers in the fibres and textile industry should pay more attention to their workers' satisfaction, assuming that an increased level of satisfaction can contribute to an increased work efficiency, bringing measurable results.

\section{Limitations}

In the study, there were some limitations, including:

- the data was collected using a completed questionnaire. Thus, the researcher was dependent on the voluntary cooperation of respondents;

- the study was limited to selected job satisfaction factors;

- the size of the research sample was not large enough to generalize the conclusions; the study was conducted using a self-designed questionnaire.

An obstacle in the search for the factors conditioning satisfaction with work is, among others, a personalized approach of employees to entrusted duties and individual satisfaction with work. While closely considering the factors conditioning satisfaction, one should pay attention to different workplaces, job specifics, type and nature of the activities carried out by the employer, as well as age, sex, life situation, etc. of the respondents. The scope of such research could be interesting, but very extensive.

\section{Perspectives}

Due to the fact that for modern SMEs the problem of job satisfaction becomes both an objective and a measure of organizational efficiency, future research could concern a process of shaping SME workers' satisfaction as well as which of the above-mentioned factors are of a particular importance. Further research could therefore focus on better recognition of 
shaping the process of the employee satisfaction and, consequently, on attempts to determine the impact of workers' satisfaction on their behavior.

\section{References}

Abun, D., Magallanez, T., Foronda, S.L.G.L \& Agoot, F. (2019). Measuring Basic Psychological Need Satisfaction and Frustration and Work Engagement of Employees of Divine Word Colleges in Ilocos Region, Philippines. International Journal of English Literature and Social Sciences, 4(2), 306-321.

Babikova, K., \& Bucek, J. (2019). A model replication with an extension of students' perception of prospective employer attractiveness. Journal of Competitiveness, 11(2), 5.

Basma, K., Fais, A. and Yeoh, K.K. (2017). Job Satisfaction and Intention to Leave in SME Construction Companies of United Arab Emirates (UAE). Business Management Dynamics, 7(03), 1-9.

Bourdieu, P. (1986). The Forms of Capital. In J.G., Richardson (Ed.), Handbook of theory and research for the sociology of education, pp. 241-258, New York: Greenwood Press.

Bourdieu, P. and Wacquant, L.J.D. (1992). An Invitation to Reflexive Sociology, Chicago: University of Chicago Press.

Bugdol, M. (2006), Wartości organizacyjne. Szkice z teorii organizacji zarzadzania. Kraków: Wydawnictwo UJ.

Cannas, M., Sergi, B. S., Sironi, E., \& Mentel, U. (2019). Job satisfaction and subjective wellbeing in Europe. Economics \& Sociology, 12(4), 183-332.

Cichowicz, E. and Rollnik-Sadowska, E. (2018). Inclusive Growth in CEE Countries as a Determinant of Sustainable Development. Sustainability, 10(11), 3973.

Coleman, J.S. (1990). Foundations of Social Theory, Cambrigde: Harvard University Press.

Czapiński, J. and Panek, T. (Ed.) (2015). Diagnoza Społeczna 2015. Warunki i jakość życia Polaków, Warszawa: Rada Monitoringu Społecznego.

Czarnota-Bojarska, J. (2010). Dopasowanie człowiek - organizacja $i$ tożsamość organizacyjna. Warszawa: Wydawnictwo Naukowe Scholar.

Davis, G. (2004). Job satisfaction survey among employees in small businesses. Journal of Small Business and Enterprise Development, 11(4), 495-503.

Devaney, S.A. and Chen, Z. (2003). Job Satisfaction of Recent Graduates in Financial Services. Purdue University, West Lafayette. Retrieved April 12, 2019, from https://www.bls.gov/opub/mlr/cwc/job-satisfaction-of-recent-graduates-in-financialservices.pdf

Dzieńdziora, J. (2010). Wybrane aspekty zarządzania zasobami ludzkimi w świetle badań ankietowych MSP. In J. Kramer, \& Dzieńdziora, J. (Eds.), Nowe trendy w zarzadzaniu przedsiębiorstwem, Bielsko-Biała: Wydawnictwo Wyższej Szkoły EkonomicznoHumanistycznej.

Ensour, W., Zeglat, D., and Shrafat, F. (2018). Impact of job satisfaction on training motivation. Problems and Perspectives in Management, 16(3), 337-355. https://doi.org/10.21511/ppm.16(3).2018.27

European Commission. (2018 November). Annual Report on European SMEs 2017/2018: SMEs growing beyond borders. Retrieved March 10, 2019, from https://publications.europa.eu/en/home.

Eurostat. (2019). Databases. Retrieved April 7, 2019, form https://ec.europa.eu/eurostat/data/database.

Faggianelli, D., Burlacu, S., \& Carra, C. (2018). Victimization of health professionals in Bucharest service relations and social work relationships. Administratie si Management Public, 30, 109-126. 
Fukuyama, F. (2003). Kapitał społeczny. In L.E. Harrison, \& S.P. Huntington (Eds.), Kultura ma znaczenie, Kraków: Zysk i S-ka.

Gazioglu, S. and Tanselb, A. (2006). Job Satisfaction in Britain: Individual and Job Related Factors. Applied Economics, 38(10), 1163-1171.

Glover, T.D. and Hemingway, J.L. (2005). Locating Leisure in the Social Capital Literature, Journal of Leisure Research, 31(4), 387-402.

Gros, U. (2012). Zachowania organizacyjne $w$ teorii i praktyce zarzadzania. Warszawa: Wydawnictwo Naukowe PWN.

Hanaysha, J. (2016). Examining the Effects of Employee Empowerment, Teamwork, and Employee Training on Organizational Commitment. Procedia - Social and Behavioral Sciences, 229, 298-306.

Hellriegel, D., Locum, J.W. and Woodman, E.W. (1995). Organizational Behavior. Minneapolis: West Publishing Company.

Ignasiak-Szulc, A. and Kosiedowski, W. (2016). Gospodarka państw Europy ŚrodkowoWschodniej w okresie kryzysowych turbulencji. Zeszyty Naukowe Uniwersytetu Ekonomicznego w Krakowie, 12(960), 21-39.

Ilies, R. and Judge T.A. (2004). An experience-sampling measure of job satisfaction and its relationship with affectivity, mood at work, job beliefs, and general job satisfaction. European Journal of Work and Oganizational Psychology, 13, 367-389.

Jeremiah, A., Rust, A., and Martin, J. (2019). Prognosticating job satisfaction and morale determinants of public Technical Vocational Education and Training (TVET) educators. Problems and Perspectives in Management, 17(3), 350-361. https://doi.org/10.21511/ppm.17(3).2019.28

Juchnowicz, M. (2014). Satysfakcja zawodowa pracowników. Kreator kapitału ludzkiego, Warszawa: Polskie Wydawnictwo Ekonomiczne.

Judge, T.A., Piccolo, R.F., Podsakoff, N.P., Shaw, J.C. \& Rich B.L. (2010). The relationship between pay and job satisfaction: A meta-analysis of the literature. Journal of Vocational Behavior, 77, 157-167.

Jun, M. , Cai, S. and Shin, H. (2006). TQM practice in maquiladora: Antecedents of employee satisfaction and loyalty. Journal of Operations Management, 24(6), 791-812.

Keeley, B. (2017). Human Capital. How what you know shapes your life. Paris: OECD.

Koišová, E., Grmanová, E., \& Habánik, J. (2018). Regional disparities in financing innovations in small and medium-sized enterprises. Journal of International Studies, 11(3), 124.

Kuzkin, Y., Cherkashyna, T., Nebaba N., and Kuchmacz, B. (2019). Economic growth of the country and national intellectual capital (evidence from the post-socialist countries of the central and eastern Europe). Problems and Perspectives in Management, 17(1), 348359. https://doi.org/10.21511/ppm.17(1).2019.30

Legatum Institute (2018), The Legatum Prosperity Index ${ }^{T M}$ 2018. London: The Legatum Institute Foundation.

Lewicka, D. (2010). Zarzadzanie kapitałem ludzkim w polskich przedsiębiorstwach. Metody, narzędzia, mierniki, Warszawa: Wydawnictwo Naukowe PWN.

Lindzey, G. and Aronson, E. (1985). Handbook of Social Psychology, New York: Random House.

Locke, E.A. (1976). The Nature and Causes of Job Satisfaction. Handbook of Industrial and Organizational Psychology. Chicago: Rand McNally College Publishing Company.

Lu, S. (2018). State of the EU Textile and Apparel Industry. Retrieved April 5, 2019, form https://shenglufashion.com/2018/04/. 
Lumley, E.J., Coetzee, M., Tladinyane, R. \& Ferreira N. (2011). Exploring the job satisfaction and organizational commitment of employees in the information technology environment. Southern African Business Review, 15(1), 100-118.

Marjański, A., Sułkowski, Ł., Marjańska-Potakowska, J., \& Staniszewska, K. (2019). Social capital drives SME growth: A study of family firms in Poland. German Journal of Human Resource Management, 33(3), 280-304. https://doi.org/10.1177/2397002219847668

Markowska-Przybyła, U. \& Ramsey, D.M. (2017). Kapitał społeczny polskich studentów na tle międzynarodowym z wykorzystaniem wyników badań eksperymentalnych. Przegląd Socjologiczny, LXVI/2, 9-36.

Mishchuk, H., \& Grishnova, O. (2015). Empirical study of the comfort of living and working environment-Ukraine and Europe: comparative assessment. Journal of International Studies, 8(1), 67 - 80. https://doi.org/10.14254/2071-8330.2015/8-1/6

Mishchuk, H., Samoliuk, N., \& Bilan, Y. (2019). Measuring social justice in the light of effectiveness of public distributive policy. Administration \& Public Management Review, 32, 63-76. https://doi.org/10.24818/amp/2019.32-05.

Musteen, M., Francis, J. \& Datta, D.K. (2010). The influence of international networks on internationalization speed and performance: A study of Czech SMEs. Journal of World Business, 45, 197-205.

OECD. Glossary of Statistical Terms. Central and Eastern European Countries (CEECs). Retrieved April 15, 2019, from https://stats.oecd.org/glossary/detail.asp?ID=303

Potočnik Slavič, I. (2009). Socjalni kapital na slovenskem podeželju. Dela, 31, 21-36.

Putnam, R. (1995). Demokracja $w$ działaniu. Kraków: Fundacja im. Stefana Batorego „Znak”.

Raszkowski, A. \& Bartniczak, B. (2019). Sustainable Development in the Central and Eastern European Countries (CEECs): Challenges and Opportunities. Sustainability, 11(4), 1180. https://doi.org/10.3390/su11041180

Raziq, A. \& Maulabakhsh R. (2015). Impact of Working Environment on Job Satisfaction. Procedia Economics and Finance, 23,717-725. https://doi.org/10.1016/S22125671(15)00524-9

Reijseger, G., Peeters, M.C.W., Taris, T.W. \& Schaufeli, W.B. (2017). From Motivation to Activation: Why Engaged Workers are Better Performers. Journal of Business and Psychology, 32, 117-130.

Rusu, V.D. \& Roman, A. (2017). Economic Performance of the SME sector in CEE Countries: an Empirical Investigation. Acta Universtais Danubius, 13(3), 102-114.

Šajn, N. (2019). Environmental impact of the textile and clothing industry, Briefing. European Parliamentary Research Service, PE 633.143, 1-10.

Sandal, J.U, Yakobchuk, V., Lytvynchuk, I. \& Plotnikova, M. (2019). Institutions for forming social capital in territorial communities. Management Theory and Studies for Rural Business and Infrastructure Development, 41(1), 67-76.

Sandal, J.U. (2017). How innovation maintains and develops democracy. Economic Annals$X X I, 165(5-6), 23-26$.

Schultz, D. \& Schultz, S.E. (2008). Psychologia a wyzwania dzisiejszej pracy. Warszawa: Wydawnictwo Naukowe PWN.

Schwab, K., Word Economic Forum (Eds.) (2018). The Global Competitiveness Report 2018. Geneva: Word Economic Forum.

Sehunoe, N., Viviers, A.M. \& Mayer, C-H. (2015). Job satisfaction, organizational commitment and work engagement in an insurance company. South African Journal of Labour Relations, 39(2), 123-144. 
SHRM. (2017). Employee Job Satisfaction and Engagement: The Doors of Opportunity Are Open. Retrieved April 12, 2019, from https://www.shrm.org/hr-today/trends-andforecasting/research-and-surveys/Documents/2017-Employee-Job-Satisfaction-andEngagement-Executive-Summary.pdf

Sierocińska, K. (2011). Kapitał społeczny. Definiowanie, pomiar i typy. Studia Ekonomiczne, (1), 69-86.

Sikora, J. (2000). Motywowanie pracowników. Bydgoszcz: OPO.

Singh, L.B. (2017). Job Satisfaction as a Predictor of Employee Engagement. Amity Global HRM Review, September, 20-30.

Skalli, A., Theodossiou, I., \& Vasileiou, E. (2008). Jobs as Lancaster Goods: Facets of Job Satisfaction and Overall Job Satisfaction. The Journal of Socio-Economics, 37(5), 1906-1920. https://doi.org/10.1016/j.socec.2008.04.003

Skrodzka, I. (2018). Social capital and smart growth of the EU countries. Economic and Environmental Studies, 18(2), 841-858. https://doi.org/10.25167/ees.2018.46.23

Smętkowski, M., \& Wójcik, K. (2008). Regiony w Europie Środkowo-Wschodniej. Tendencje $i$ czynniki rozwojowe. Warszawa: Centrum Europejskich Studiów Regionalnych, Uniwersytet Warszawski.

SolAbility. (2017). The Sustainable Competitiveness Index, Zurich: SolAbility.

Sousa-Poza, A. \& Sousa-Poza, A. (2000). Taking Another Look at the Gender/JobSatisfaction Paradox. Kyklos, 53(2), 135-152. https://doi.org/10.1111/1467-6435.00114

Sowińska, A. (2014). Zadowolenie z pracy - problemy definicyjne. Studia Ekonomiczne, $197 / 4,45-56$.

Springer, A. (2011). Wybrane czynniki kształtujące satysfakcję pracowników. Problemy Zarzadzania, 9(4), 162-180.

Staples, D.S. \& Higgins, C.A. (1998). A Study of the Impact of Factor Importance Weightings on Job Satisfaction Measures. Journal of Business and Psychology, 13(2), 211-232.

Sułkowski, Ł. (2017). Social Capital, Trust and Intercultural Interactions. In: Rozkwitalska M., Sułkowski Ł. and Magala S. (Eds.), Intercultural Interactions in the Multicultural Workplace. Contributions to Management Science. Cham: Springer.

Textiles and clothing in the EU. Retrieved April 4, 2019, from https://ec.europa.eu/growth/sectors/fashion/textiles-clothing/eu_de

Vladimirova, K. (Ed.) (2008). Flexible employment and security in SMEs in Bulgaria: state and trends. Sofia: Chance AD.

Vlosky, R.P., \& Aguilar, F.X. (2009). A Model of Employee Satisfaction: Gender Differences in Cooperative Extension. Journal of Extension, 47(2), 1-15.

Vroom, V.H. (1964). Work and Motivation. New York: Wiley.

Weiss, H.M. (2002). Deconstructing job satisfaction: Separating evaluations, beliefs and affective experiences. Human Resource Management Review, 12, 173-194.

Wexley, K.N. \& Yukl, G.A. (1984). Organizational Behavior Personnel Psychology, Irwin: Homewood Ill.

Wijaya, N. H. S. (2019). Linking job dissatisfaction, learning motivation, creative work involvement, and proactive personality. Problems and Perspectives in Management, 17(1), 32-41. https://doi.org/10.21511/ppm.17(1).2019.04

Wierus, K., Bierut, B., Kosior, A., \& Rzeszutko, E. (Eds.) (2017 April). Sytuacja gospodarcza $w$ krajach Europy Środkowej $i$ Wschodniej. Warszawa: Department Analiz Ekonomicznych NBP. 